\title{
Liquid Crystals Decorated Gold Nanoparticles for Photoswitching Properties
}

\author{
Md. Lutfor Rahman, ${ }^{*, a}$ Mohd Sani Sarjadi, ${ }^{a}$ Shaheen M. Sarkar, ${ }^{b}$ Mashitah M. Yusoff, ${ }^{b}$ \\ Yuvaraj A. R., ${ }^{c}$ and Sandeep $\mathrm{Kumar}^{c}$ \\ ${ }^{a}$ Faculty for Science and Natural Resources, Universiti Malaysia Sabah, 88400 Kota Kinabalu, Sabah, Malaysia \\ ${ }^{b}$ Faculty of Industrial Sciences \& Technology, Universiti Malaysia Pahang, 26300 Gambang, Kuantan, \\ Pahang, Malaysia \\ ${ }^{c}$ Raman Research Institute, Raman Avenue, Sadashivanagar, Bangalore 560080, India
}

Email: lutfor73@gmail.com (M. L. R.)

\begin{abstract}
Liquid crystals decorated gold nanoparticles are synthesized as the molecular architecture consists of the azobenzenes moieties with alkene as the peripheral units, which are connected to gold nanoparticles (Au-NPs) via thiolated phenolic units are in the middle. The morphology and mesomorphic properties were investigated by the field emission scanning electron microscope, high-resolution transmission electron microscopy, differential scanning calorimetry, and polarizing optical microscopy. The aromatic thiolated azobenzene moieties with gold nanoparticles showed smectic A phase with monotropic nature only appeared in the cooling cycle. HR-TEM measurement showed that the functionalized Au-NPs are well dispersed without any aggregation. However, the absorption spectrum of peripheral azobenzene units shows strong absorption maxima in the ultraviolet region at $378 \mathrm{~nm}$ due to $\pi-\pi^{*}$ transition. For $n-\pi^{*}$ transition, a weak absorption band is observed in the visible region at $472 \mathrm{~nm}$. The photo-isomerization characteristic is measured using absorption spectroscopy. The photosaturation of Au-NPs is found at the time duration of $16 \mathrm{~s}$. The thermal back relaxation is completed after the time interval of $70 \mathrm{~min}$. Moreover, Au-NPs showed excellent stability towards photo-decay. Therefore, Au-NPs compound is suitable in the field of optical storage and molecular switching.
\end{abstract}

Keywords liquid crystals, gold nanoparticles, photoswitching, molecular switches, optical storage

\section{Introduction}

As per the present trend, nanomaterials are extensively used in the industrial and medical applications. The investigation of nano functional materials from building block composites play an important role in the field of nanotechnology. ${ }^{[1]}$ Liquid crystal based nanocomposites are promising functional materials in order to get self-assembled matrices via structure and property relationships. ${ }^{[2]}$ Verities of potentials liquid crystal (LC) compounds are implemented in display devices, namely liquid crystal displays (LCDs). These LCs are employed in several applications, such as lasing devices, controllable lenses, photonic band gap structures, drug delivery vehicles and sensors. ${ }^{[3]}$ Recently, self-assembled quasi-spherical gold nanoparticle based LCs are reported and they displayed smectic/nematic phases. ${ }^{[4]}$ In the LC history, Brust et al. ${ }^{[5]}$ introduced the concept of functionalization of gold nanoparticle surface using thiols. Usually, Au-NPs are stable towards moisture, atmospheric air and atmospheric temperature only if the alkyl chain $\left(\mathrm{C}_{n} \mathrm{H}_{2 n+1} \mathrm{SH}\right)$ length is not more than twelve $\left(\mathrm{C}_{12} \mathrm{H}_{25} \mathrm{SH}\right)$. Hao et al. ${ }^{[6]}$ observed the variation of size $(\approx 2 \mathrm{~nm})$ of gold nanoclusters with increasing temperature. The variation of particle size is probably due to the Ostwald ripening phenomenon via the release of thiols from the metallic surface. ${ }^{[7]}$ Müller et al. ${ }^{[8]}$ demonstrated the light scattering using quasi-spherical gold nanoclusters in the nematic LC matrix. The enhancement of surface plasmon splitting is evaluated using a thin film of gold nanoparticle in nematic LC composite and this is reported by Park et al ${ }^{[9]}$ Using an Au-NPs nematic LC cell, gold nanodot array is fabricated and colour tuning is achieved with respect to variable applied voltage. The nature of nanoparticle dispersion in the display devices affects contrast ratio, dielectric behaviour, pretilt angle and threshold voltage. ${ }^{[10-14]}$ This surface behaviour of the display devices could be altered by localization of Au-NPs surface plasmon resonance. ${ }^{[15]}$ LCs plays a main role in the alteration of optical and electronic characteristics of Au-NP assembly. ${ }^{[16]}$ On the other hand, LC property of the composite could be drastically affected by Au-NPs dopants, which may lead to enhance the alignment ${ }^{[17]}$ and electro-optical characteristics. ${ }^{[12]}$ Essentially, LC functionalized Au-NPs changes the textural and alignment of the device. Hao et al. ${ }^{[6]}$ used ITO coated by polyimide and rubbed cells, and they reported unprecedented dual electro-optic mode and alignment. In such cases, the planar alignment is obtained from homeotropic alignment by the applied electric field. ${ }^{[13]}$ Nevertheless, a very limited number of Au-NP functionalized materials are implemented in the commercial display applications.

Apart from the synthesis and design of LC based Au-NPs, the researchers are also interested in the light induced characteristics of them. It means the molecular ordering and disordering are controlled by incident light. The high-speed information process technology is mainly controlled by incident light from the external source. Several light induced an isothermal phase transition of various LCs is evaluated by Prasad et al. ${ }^{[18-20]}$ Interestingly, the photo-switchable $\mathrm{N}=\mathrm{N}$ group, which is chemically bonded or used as guest in the LC media, attracted significantly in the recent era. ${ }^{[21-25]}$ This is because of dramatic molecular shape transformation with respect to the incident light energy. The molecular shape change is due to the isom- 


\section{Report}

erisation of photochromic azobenzene moiety. Energetically, more stable trans form isomerises to cis form upon illumination of ultraviolet radiation. The reverse transformation is called thermal back relaxation and it is a spontaneous process. ${ }^{[21-27]}$ Herein, rod shaped azobenzene bridges become bent shaped upon irradiation of ultraviolet light. This destabilization affects a lot in the transition temperature of LC and one can recognise the lowering of isotropic transition in most of the cases. ${ }^{[28]}$

Recently, our group reported a series of liquid crystals decorated gold nanoparticles, whose molecular architecture has azobenzenes moieties with ketone functional groups as the peripheral units connected to gold nanoparticles via alkyl groups (C4-C6). ${ }^{[29]}$ Those compounds exhibit nematic and smectic A phases. The present paper is different with the reported paper in terms of molecular structure. ${ }^{[29]}$ The compound is composed with phenyl and alkene instead of alkyl chains and ketone groups, respectively. The mesophase properties are also different as the present compound exhibits only SmA phase with monotropic nature. The photoisomerization experiment proved that the optical storage ability of the Au-NPs material.

\section{Experimental}

\section{Synthesis of intermediate compounds}

All intermediate compounds 1-3 were synthesized according to our earlier paper (Scheme 1). ${ }^{[30-33]}$

Ethyl 4-[(4-hydroxyphenyl)diazenyl]benzoate (1). IR ( $\mathrm{KBr}) v$ : $3320(\mathrm{OH}), 1725(\mathrm{C}=\mathrm{O}$, ester), 1602, $1481(\mathrm{C}=\mathrm{C}$, aromatic), 1248, 1140 (C-O), 827 (C-H) cm ${ }^{-1} .{ }^{1} \mathrm{H}$ NMR $(500 \mathrm{MHz}$, acetone- $\left.d_{6}, \mathrm{Me}_{4} \mathrm{Si}\right) \delta 8.15(2 \mathrm{H}, \mathrm{d}, J=8.1 \mathrm{~Hz}, \mathrm{Ph}), 7.91(2 \mathrm{H}, \mathrm{d}, J=$ $6.9 \mathrm{~Hz}, \mathrm{Ph}), 7.89(2 \mathrm{H}, \mathrm{d}, J=7.7 \mathrm{~Hz}, \mathrm{Ph}), 7.0(2 \mathrm{H}, \mathrm{d}, J=8.9 \mathrm{~Hz}$, $\mathrm{Ph}), 5.59(1 \mathrm{H}, \mathrm{s}, \mathrm{OH}), 4.41\left(2 \mathrm{H}, \mathrm{q}, J=6.8 \mathrm{~Hz}, \mathrm{CH}_{2} \mathrm{CH}_{3}\right), 1.44$ $\left(3 \mathrm{H}, \mathrm{CH}_{2} \mathrm{CH}_{3}\right) .{ }^{13} \mathrm{C}$ NMR $\left(125 \mathrm{MHz}\right.$, acetone- $\left.d_{6}, \mathrm{Me}_{4} \mathrm{Si}\right) \delta: 14.51$, $61.42,116.21,122.58,125.57,130.69,131.61,147.20,155.42$, $159.23,166.42$

Ethyl4-\{2-[4-(prop-2-enyloxy)phenyl]hydrazinyl\}benzoate (2). IR (KBr) v: $3077\left(=\mathrm{CH}_{2}\right), 2926\left(\mathrm{CH}_{2}\right), 2860\left(\mathrm{CH}_{2}\right), 1727$ ( $\mathrm{C}=\mathrm{O}$, ester), $1640(\mathrm{C}=\mathrm{C}$, vinyl), 1604, $1495(\mathrm{C}=\mathrm{C}$, aromatic), 1241, 1132, 1062 (C-O), $826(\mathrm{C}-\mathrm{H}) \mathrm{cm}^{-1} .{ }^{1} \mathrm{H}$ NMR $(500 \mathrm{MHz}$, $\left.\mathrm{CDCl}_{3}, \mathrm{Me}_{4} \mathrm{Si}\right) \delta: \quad 8.16(2 \mathrm{H}, \mathrm{d}, J=8.5 \mathrm{~Hz}, \mathrm{Ph}), 7.96(2 \mathrm{H}, \mathrm{d}$, $J=6.8 \mathrm{~Hz}, \mathrm{Ph}), 7.90(2 \mathrm{H}, \mathrm{d}, J=6.8 \mathrm{~Hz}), 7.01(2 \mathrm{H}, \mathrm{d}, J=6.9 \mathrm{~Hz})$ $6.05(\mathrm{~m}, 1 \mathrm{H}, \mathrm{CH}=), 5.41\left(\mathrm{~d}, 1 \mathrm{H}, J=16.1 \mathrm{~Hz},=\mathrm{CH}_{2}\right), 5.30(\mathrm{~d}, 1 \mathrm{H}$, $\left.J=10.1 \mathrm{~Hz},=\mathrm{CH}_{2}\right), 4.62\left(\mathrm{~d}, 2 \mathrm{H}, J=4.8 \mathrm{~Hz}, \mathrm{OCH}_{2}\right), 4.16(\mathrm{q}, 2 \mathrm{H}$, $\left.\mathrm{OCH}_{2} \mathrm{CH}_{3}\right), 1.42$ (t, 3H, $\left.\mathrm{CH}_{2} \mathrm{CH}_{3}\right) .{ }^{13} \mathrm{C}$ NMR $\left(125 \mathrm{MHz}, \mathrm{CDCl}_{3}\right.$, $\left.\mathrm{Me}_{4} \mathrm{Si}\right) \delta: 14.50,61.39,69.20,115.21,118.22,122.62,125.25$, $130.21,131.34,132.31,147.24,155.44,161.80,166.45$.

4-\{2-[4-(Prop-2-enyloxy)phenyl]hydrazinyl\}benzoic acid (3). IR (KBr) v: $3074\left(=\mathrm{CH}_{2}\right), 2920\left(\mathrm{CH}_{2}\right), 2862\left(\mathrm{CH}_{2}\right), 1684$ $(\mathrm{C}=\mathrm{O}, \mathrm{acid}), 1642(\mathrm{C}=\mathrm{C}$, vinyl), 1599, $1492(\mathrm{C}=\mathrm{C}$, aromatic), 1245, 1136, $1062(\mathrm{C}-\mathrm{O}), 826(\mathrm{C}-\mathrm{H}) \mathrm{cm}^{-1} .{ }^{1} \mathrm{H}$ NMR $(500 \mathrm{MHz}$, $\left.\mathrm{CDCl}_{3}, \mathrm{Me}_{4} \mathrm{Si}\right) \delta: 8.17(2 \mathrm{H}, \mathrm{d}, J=8.1 \mathrm{~Hz}), 7.97(2 \mathrm{H}, \mathrm{d}, J=6.8$ $\mathrm{Hz}), 7.92(2 \mathrm{H}, \mathrm{d}, J=6.8 \mathrm{~Hz}), 7.04(2 \mathrm{H}, \mathrm{d}, J=8.8 \mathrm{~Hz}), 6.05(\mathrm{~m}$, $1 \mathrm{H}, \mathrm{CH}=), 5.43\left(\mathrm{~d}, 1 \mathrm{H}, J=16.2 \mathrm{~Hz},=\mathrm{CH}_{2}\right), 5.30(\mathrm{~d}, 1 \mathrm{H}, J=10.1$ $\left.\mathrm{Hz},=\mathrm{CH}_{2}\right), 4.61\left(\mathrm{~d}, 2 \mathrm{H}, J=4.2 \mathrm{~Hz}, \mathrm{OCH}_{2}\right) \cdot{ }^{13} \mathrm{C} \mathrm{NMR}(125 \mathrm{MHz}$, $\left.\mathrm{CDCl}_{3}, \mathrm{Me}_{4} \mathrm{Si}\right) \delta: 69.15,115.16,118.22,122.42,125.22,130.62$, $131.65,132.71,147.21,155.40,161.68,166.95$.

\section{Synthesis of aromatic linked thiolated gold nanoparticle} (4)

To a stirred solution of tetraoctylammonium bromide $(0.50 \mathrm{~g}$ $0.917 \mathrm{mmol})$ in toluene $(15 \mathrm{~mL}$ ) was added an aqueous solution $(10 \mathrm{~mL})$ of gold(III) chloride trihydrate $(0.145 \mathrm{~g}, 0.368 \mathrm{mmol})$ and the mixture was stirred for $30 \mathrm{~min}^{[34-36]}$ The reaction mix- ture was washed with distilled water and the organic layer was separated. Then 4-mercaptophenol $(0.100 \mathrm{~g}, 0.80 \mathrm{mmol})$ in toluene $(5 \mathrm{~mL})$ was added to the above solution and the resulting mixture will be stirred for $30 \mathrm{~min}$. An aqueous solution of sodium borohydride $(0.120 \mathrm{~g}, 3.15 \mathrm{mmol})$ was added drop-wise and the mixture is stirred for a further period of $6 \mathrm{~h}$. The organic layer was washed with water and dilute with methanol $(50 \mathrm{~mL})$. It was kept in a refrigerator, and the precipitate obtained is further purified by being re-suspending in toluene and then the addition of methanol $(10 \mathrm{~mL})$. This process was repeated to remove any unbound thiol for pure Au-NP of 4 . The purification procedure repeated until no trace of excess of thiol could be found in the ${ }^{1} \mathrm{H}$ NMR spectrum (signal absence at $2.56 \mathrm{ppm}$, proton NMR) and TLC. IR (KBr) v: $3470(\mathrm{OH}), 1601,1490(\mathrm{C}=\mathrm{C}$, aromatic), 1240, 1060 (C-O), $822(\mathrm{C}-\mathrm{H}) \mathrm{cm}^{-1} .{ }^{1} \mathrm{H}$ NMR (500 $\left.\mathrm{MHz}, \mathrm{CDCl}_{3}, \mathrm{Me}_{4} \mathrm{Si}\right) \delta .7 .13(2 \mathrm{H}, \mathrm{d}, J=6.1 \mathrm{~Hz}), 6.70(2 \mathrm{H}, \mathrm{d}, J=$ $6.2 \mathrm{~Hz}), 4.86$ (s, 1H, $\mathrm{PhOH}$ )

\section{Liquid crystals linked with gold nanoparticles (5)}

Synthesis of liquid crystals decorated gold nanoparticle (5). A solution was prepared by dissolving $40 \mathrm{mg}$ of gold nanoparticles of $\mathbf{4}$ in $5 \mathrm{~mL}$ of DMF. ${ }^{[35,37]}$ The azobenzene with the terminal alkene of carboxylic acid functional groups of $3(45 \mathrm{mg})$ was dissolved in $10 \mathrm{~mL}$ of dichloromethane added with stirring. The mixture was added with DCC (50 mg) and DMAP $(5 \mathrm{mg})$, and it was stirred for $24 \mathrm{~h}$. The precipitate was removed by filtration and the solvent was removed by reduced pressure. The residue was re-dissolved in dichloromethane $(50 \mathrm{~mL})$, then few drops of acetic acid and distil water $(50 \mathrm{~mL})$ was added. The mixture was taken in separating funnel and the organic layer was separated and washed with water. The solvent was evaporated and the solid was recrystallized from ethanol and chloroform to get the target compound 5. IR $(\mathrm{KBr})$ v: $3085\left(=\mathrm{CH}_{2}\right), 2922\left(\mathrm{CH}_{2}\right)$, $2864\left(\mathrm{CH}_{2}\right), 1742$ ( $\mathrm{C}=\mathrm{O}$, ester), $1642(\mathrm{C}=\mathrm{C}$, vinyl), 1600, 1491 $1404\left(\mathrm{C}=\mathrm{C}\right.$, aromatic), 1243, 1136, $1061(\mathrm{C}-\mathrm{O}), 825(\mathrm{C}-\mathrm{H}) \mathrm{cm}^{-1}$. ${ }^{1} \mathrm{H}$ NMR $\left(500 \mathrm{MHz}, \mathrm{CDCl}_{3}, \mathrm{Me}_{4} \mathrm{Si}\right) \delta: 8.18(2 \mathrm{H}, \mathrm{d}, J=8.6 \mathrm{~Hz})$, $7.97(2 \mathrm{H}, \mathrm{d}, J=7.3 \mathrm{~Hz}), 7.92(2 \mathrm{H}, \mathrm{d}, J=6.9 \mathrm{~Hz}), 7.70(2 \mathrm{H}, \mathrm{d}$ $J=6.2 \mathrm{~Hz}), 7.05(2 \mathrm{H}, \mathrm{d}, J=8.7 \mathrm{~Hz}), 7.03(2 \mathrm{H}, \mathrm{d}, J=6.3 \mathrm{~Hz})$, $5.93(\mathrm{~m}, 1 \mathrm{H}, \mathrm{CH}=), 5.12\left(\mathrm{~d}, 1 \mathrm{H}, J=16.3 \mathrm{~Hz},=\mathrm{CH}_{2}\right), 5.06(\mathrm{~d}, 1 \mathrm{H}$ $\left.J=10.2 \mathrm{~Hz},=\mathrm{CH}_{2}\right), 4.10\left(\mathrm{~d}, 2 \mathrm{H}, J=4.2 \mathrm{~Hz}, \mathrm{OCH}_{2}\right)$

\section{Characterizations}

The structure of the compounds was confirmed by the spectroscopic method. IR spectra were recorded with a Perkin Elmer (670) FTIR spectrometer. ${ }^{1} \mathrm{H}$ NMR $(500 \mathrm{MHz})$ and ${ }^{13} \mathrm{C}$ NMR $(125 \mathrm{MHz})$ spectra were recorded with a Bruker (DMX500) spectrometer. The transition temperatures and their enthalpies were measured by differential scanning calorimetry (Perkin DSC 7) with heating and cooling rates were $10^{\circ} \mathrm{C} \cdot \mathrm{min}^{-1}$. Optical textures were obtained by using Olympus BX51 polarizing optical microscope attached with Olympus DP26 digital camera equipped with a Linkam hot stage (THMS600) and a central processor unit. FE-SEM was used to study the morphology with JEOL (JSM-7800F). TEM was measured with Hitachi instrument (HT-7700). Absorption spectra for photochromic study were recorded using an Ocean Optics HR2000+ miniature UV-Vis spectrophotometer. All the solutions were prepared and measured under air in the dark at room temperature $\left(21 \pm 1^{\circ} \mathrm{C}\right)$ using $1 \mathrm{~cm}$ quartz cells. The cells were closed to avoid the evaporation of the solvent and the solutions were stirred during the irradiation time. The solutions were irradiated at $\lambda_{\max }=365$ $\mathrm{nm}$ along with heat filter to avoid any extra heat radiation to the sample using Omnicure S2000 UV source. 
Scheme 1 Gold NPs functionalized using azobenzene moieties with terminal alkene.

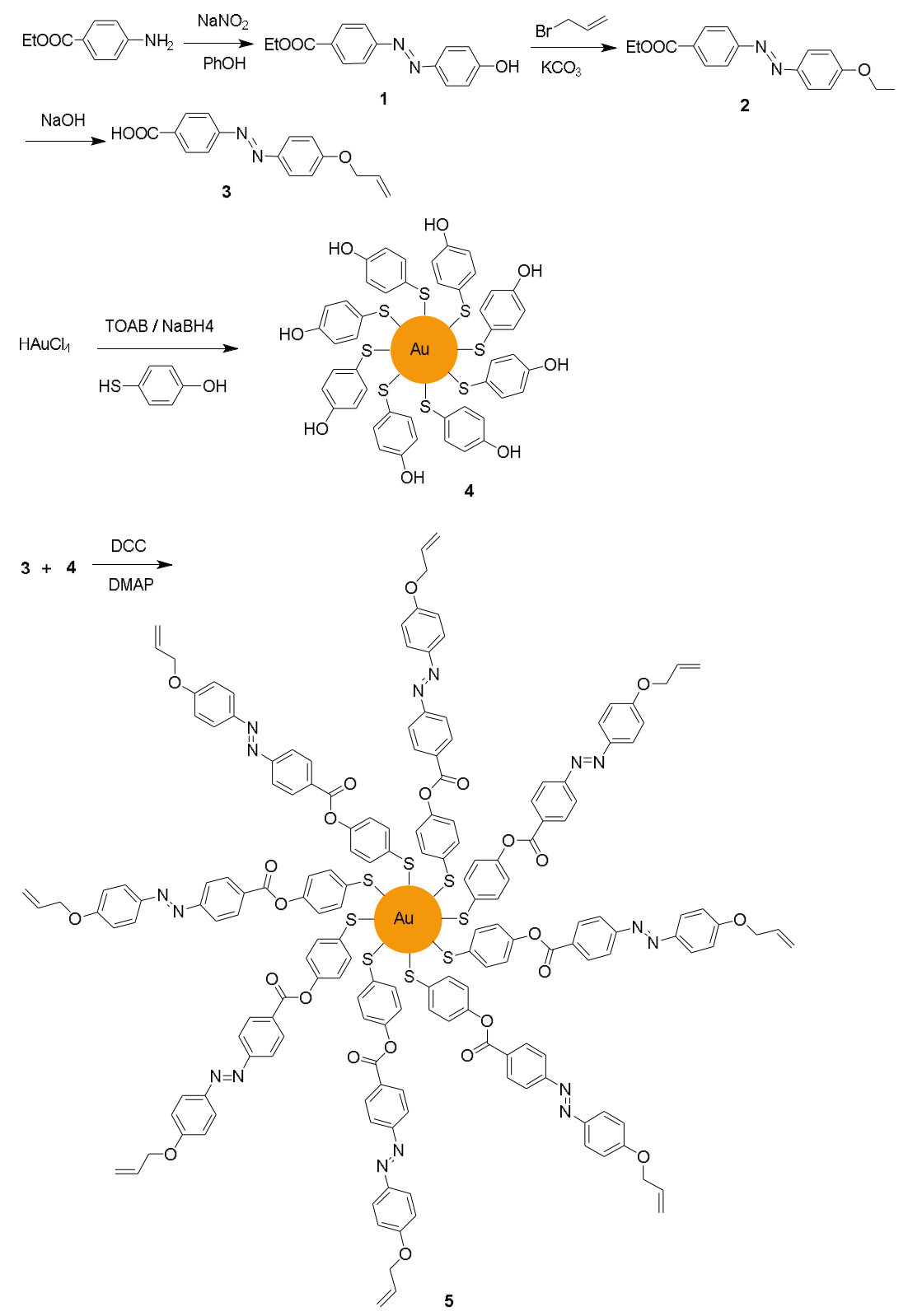

\section{Results and Discussion}

\section{Mesomorphic properties}

DSC study The phase transition temperatures were determined by differential scanning calorimetry (DSC) as shown in Figure 1. A single peak is observed in the endothermic transition, whereas two peaks are found at the exothermic transition for Au-NPs functionalized LC compound (5). On heating, for compound $\mathbf{5}$, a peak appeared at $117.5^{\circ} \mathrm{C}$ and the phase transition enthalpy change is larger $\left(\Delta H=48.5 \mathrm{~J} \cdot \mathrm{g}^{-1}\right)$, which correspond to the $\mathrm{Cr}-\mathrm{I}$ transitions. On cooling, two peaks are observed such as isotropic to SmA and SmA to crystals phase transitions occurred at $114.9\left(\Delta H=4.5 \mathrm{~J} \cdot \mathrm{g}^{-1}\right)$ and $80.0^{\circ} \mathrm{C}(\Delta H=$ $\left.40.2 \mathrm{~J} \cdot \mathrm{g}^{-1}\right)$, respectively. As can be seen, these transitions occurred at slightly lower temperature in comparison to our previous work. ${ }^{[29]}$

Polarizing optical microscopy study The mesophase structure was evaluated by means of polarizing optical microscopy (Figure 2). The mesophase of the compound 5 was observed upon cooling from the isotropic phase.

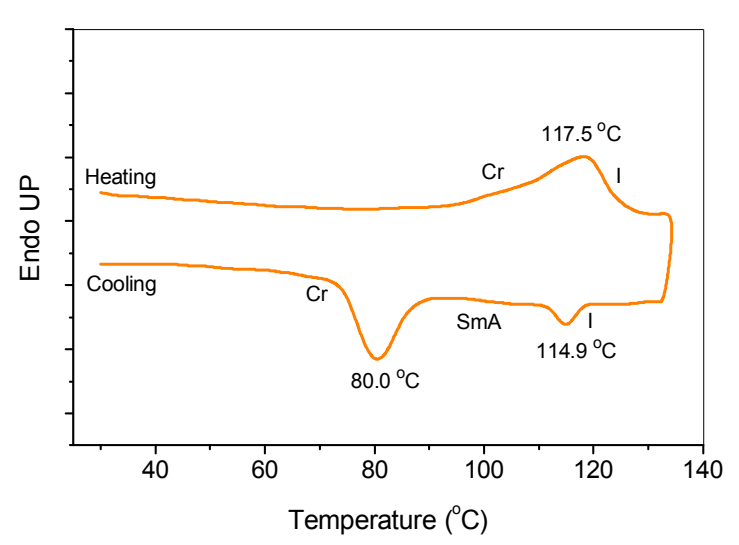

Figure 1 DSC heating and cooling traces of compound 5 at $10^{\circ} \mathrm{C} \cdot \mathrm{min}^{-1}$. 


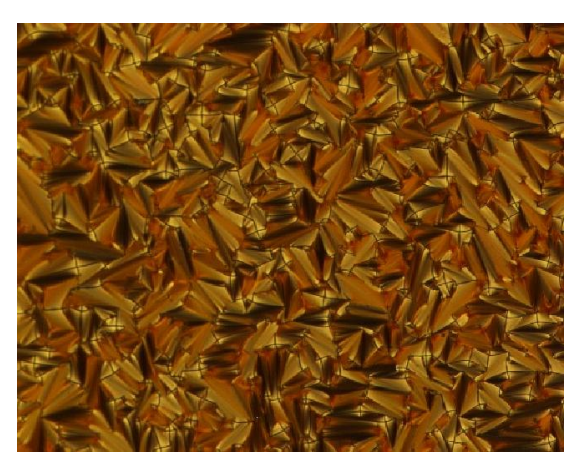

Figure 2 Optical micrographs of compound $\mathbf{5}$ on cooling from the isotropic liquid and texture of SmA phase taken at $90^{\circ} \mathrm{C}$.

The compound $\mathbf{5}$ displays typical fan shaped texture for smectic A phase upon cooling from the isotropic phase, and the texture is stable until temperature reach to $80^{\circ} \mathrm{C}$. Upon shearing, homeotropic alignment is achieved and the homeotropically aligned regions show complete darkness, which confirms the presence of a uniaxial SmA phase for the compound 5 . Therefore, the Au NP compound $\mathbf{5}$ exhibit monotropic nature because the SmA phase appears only in the cooling cycle.

FE-SEM and TEM study. FE-EM measurement was performed with JEOL instrument (JSM-7800F) instrument and photomicrograph of compound $\mathbf{5}$ is shown in Figure 3a. A compact coral like morphology was observed, which does not show any metal particles ( $\mathrm{Au}$ ) even in nano size image. Therefore, we have taken a HR-TEM image of compound 5 using Hitachi instrument (HT-7700), which consists of Au-NPs functionalized of the azobenzene liquid crystals with alkene terminal groups. TEM image was obtained by drop-casting a $5 \mu \mathrm{L}$ solution of $\mathbf{5}$ in ethanol on a carbon-coated copper grid and allowing the solvent to slowly evaporate under ambient conditions. This TEM image is shown that the functionalized Au NPs are dispersed without any aggregation (Figure $3 b$ ). The size of Au NPs on average about $5 \mathrm{~nm}$ and micrograph taken by HR-TEM as shown in Figure $4 \mathrm{~b}$.
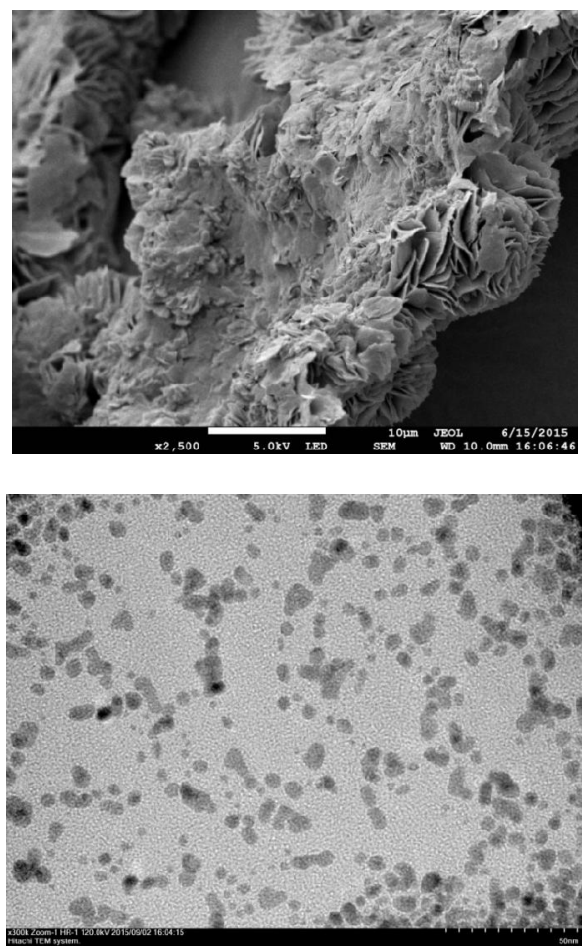

Figure 3 FE-SEM of (a) gold NPs liquid crystals of 5, (b) HRTEM micrograph of $\mathbf{5}$.

\section{Photoswitching studies}

The photoswitching properties were carried out in the solution state and the concentration was fixed at $1.5 \times 10^{-5} \mathrm{~mol} \cdot \mathrm{L}^{-1}$. The experimental evidence showed Au-NPs are good optical switches. Figure 4 shows the absorption spectra of 5 , which gives the information about photosaturation. Absorption maxima appeared at $378 \mathrm{~nm}$ for the solution of compound $\mathbf{5}$. Heat filter is installed in the system in order to avoid the instrumental errors and the intensity of radiation was kept constant 5.00 $\mathrm{mW} \cdot \mathrm{cm}^{-2}$. The value of photosaturation was determined and it is $16 \mathrm{~s}$.

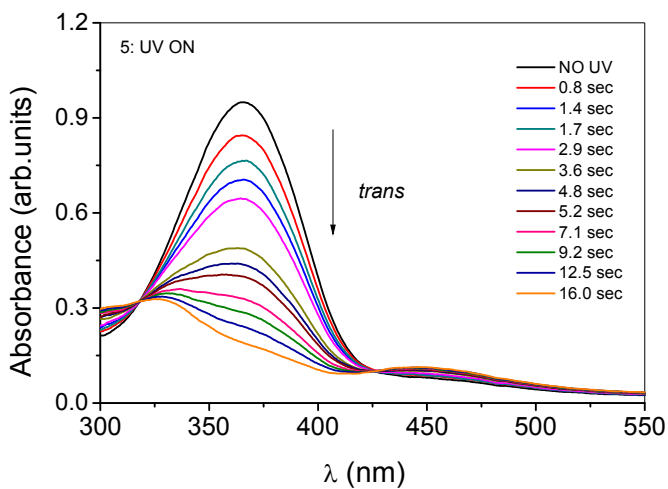

Figure 4 Time intervals were recorded for trans-cis isomerisation upon UV light irradiation.

The data in Figure 5 was obtained in the trans-cis absorption isothermal experiment. The absorption corresponds to the peak wavelength was considered and plotted the graph. The photosaturation occurred after the time interval of $16 \mathrm{~s}$. It means that nematic to isotropic phase transition could be observed after $16 \mathrm{~s}^{[18,30,31]}$

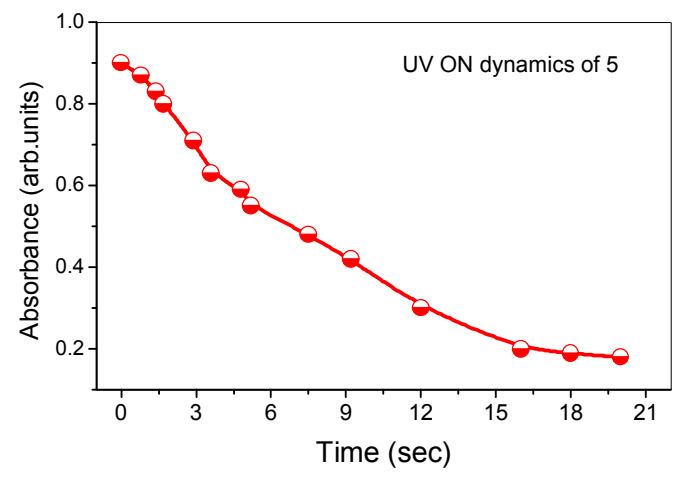

Figure 5 Isomerization as a function of illumination time interval.

The solution was irradiated for $20 \mathrm{~s}$ with the UV light and kept it in the dark state. The spontaneous thermal back relaxation was started and the subsequent time intervals were noted down, which is given in Figure 6 . Figure 7 was plotted by extracting the peak values from thermal back relaxation experiment. The recovery time was $70 \mathrm{~min}$. For the confirmation of completion of thermal back relaxation, the experiment was continued for next $10 \mathrm{~min}$. However, the corresponding absorption value did not change after $70 \mathrm{~min}$. Hence, $70 \mathrm{~min}$ is the value for the interval of thermal back relaxation. ${ }^{[18,30]}$ 
General Chemistry

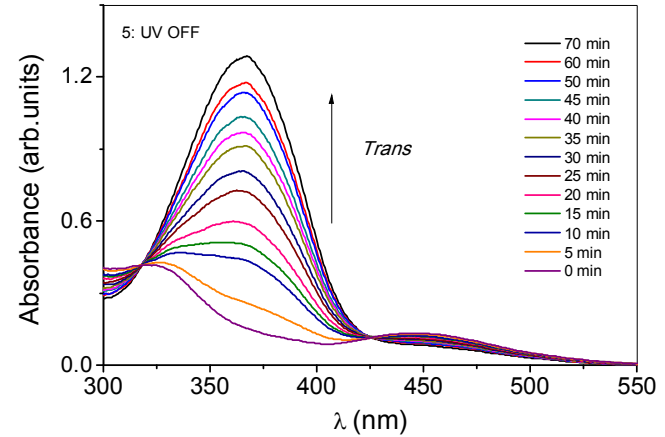

Figure 6 Spontaneous cis-trans isomerisation process.

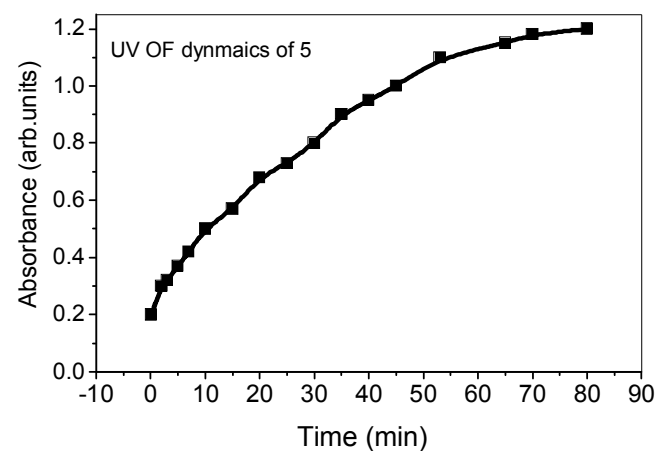

Figure 7 Thermal back relaxation against the function of recovery time.

In-plane rotation of the molecules favors the fast thermal back relaxation due to their layered structure. This was reported by Prasad et al. ${ }^{[18]}$ This hypothesis was further proved in another case, where nematic and isotropic both the phases involved have a layered structure. ${ }^{[28]}$ The rate constant for the cis-trans isomerization for the compound was calculated by the following equation 1 at room temperature. ${ }^{[33]}$

$$
\ln \frac{A_{\infty}-A_{t}}{A_{\infty}-A_{0}}=-k t
$$

where $A_{t}$ is absorbance at time $t, A_{0}$ is absorbance at time 0 and $A_{\infty}$ is absorbance at infinite time. These absorbance values were recorded at peak wavelength $378 \mathrm{~nm}$. Figure 8 depicts the first order plot of thermal back relaxation. The calculated rate constant is $1.56 \times 10^{-2} \mathrm{~s}^{-1}$ at room temperature.

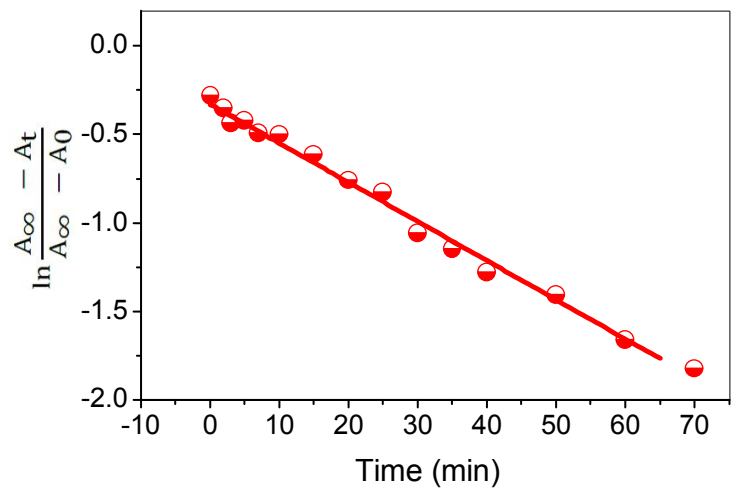

Figure 8 The first order plot for thermal back relaxation at room temperature.
Our earlier work ${ }^{[29]}$ on the functionalized gold nanoparticles showed nematic and smectic A phase with monotropic nature. Those molecules showed attractive photoisomerization behaviour, in which trans-cis transition takes about $15 \mathrm{~s}$. However the cis-trans transition requires about $45 \mathrm{~min}$ for a compound in the series. ${ }^{[29]}$ The extent of reversible isomerization did not decay after 10 cycles, which proved that those compounds were stable. Only a stable smectic A phase is obtained in the present work, and the azobenzene based gold nanoparticles is likely stable compound. ${ }^{[29]}$ Generally, nematic is less stable than smectic phase. Nematic is a liquid like phase, and it shows usually higher temperature than smectic phase. The present compound showed only smectic phase, which could give little more stable than previous one. ${ }^{[29]}$

The storage ability of azobenzene based nanoparticles and reversible optical storage ability of nanostructured $A B$ thermosets are reported in the recent work. ${ }^{[21]}$ The photo- stability of light sensitive compounds has greater importance in the field of optics and optical storage. Hence, nanostructured light sensitive compounds play a great role in the enhancement of reversible trans-cis isomerisation. Additionally, enhanced thermal back relaxation is observed in this case in comparison to our earlier report. ${ }^{[29]}$ Therefore, we can find some significant difference between the earlier work and present work with a bit different molecular structure between present work and earlier work. ${ }^{[29]}$

Due to the linear shape of trans isomeric azobenzene, the stable LC phase can be observed. However, isomerisation effect destabilizes because of the shape of cis isomeric azobenzene. Therefore, photo controlled isomerisation process enhances the transition rate from mesophase to isotropic. Prasad et al. ${ }^{[18-20]}$ reported the comprehensive studies on visual observation, absorption spectra, opto-dielectric effect and effect of pressure, random field model, disorder to order transition and dynamics of mesophase to isotropic transition. Usually, these phase transition effects could be easily noticed by polarizing optical microscope.

A shift of transition temperature induced from photoisomerization could be reduced by applied pressure. During the process of isomerization, azobenzene molecules acquire bent shape as a result volume reduces and pressure increases. ${ }^{[38]}$ This is due to the small size of cis isomeric form of azobenzene. By gaining the energy from the external source, intermolecular space decreases. Hence, there is a shift in the transition temperature by the influence of isomerisation. ${ }^{[20]}$

\section{Conclusions}

A new Au-NPs passivated with liquid crystalline molecules was synthesized, whose molecular architecture is composed of Au-NPs as central core and rod-like azobenzenes as the peripheral units linked through alkene chain. The compound of Au-NPs shows smectic A phase as monotropic nature. Experimental study suggests that this Au-NPs liquid crystal azo molecules exhibit strong photoisomerization properties. A short range of thermal back relaxation (about $70 \mathrm{~min}$ ) has potential advantages in the creation of molecular switches. The presences of the azo linkage in these liquid crystals molecules are suitable for the use of the optical storage and molecular switches.

\section{Acknowledgement}

This research was supported by FRGS grant (No. RDU130121). 


\section{Report}

\section{Supporting Information}

Supporting information for this article is available on the WWW under www.genchemistry.org/EN/10.21127/yaoyigc201 80009.

\section{Special Issue}

This paper is dedicated to the special issue of "Liquid Crystals".

\section{References}

[1] Cao, G.; Brinker, C. J. Annual Report of Nano Research, World Scientific Publishing, 2006.

[2] Gray, G. W. Handbook of Liquid Crystals, Ed.: Vill, V. Wiley-VCH, Weinheim, Germany, 1998

[3] Demus, D.; Goodby, J.; Gray, G. W.; Spiess, H. W. Handbook of Liquid Crystals, Ed.: Vill, V. Wiley-VCH, Weinheim, Germany, 1998.

[4] Cseh, L.; Mehl, G. H. J. Am. Chem. Soc. 2006, 128, 13376.

[5] Brust, M.; Walker, M.; Bethell, D.; Schiffrin, D. J.; Whyman, R. J. Chem. Commun. 1994, 801.

[6] Hao, Q.; Hegmann, T. ACS Appl. Mater. Inter. 2009, 1, 1731.

[7] Chen, Y.; Palmer, R. E.; Wilcoxon, J. P. Langmuir 2006, 22, 2851.

[8] Müller, J.; Sonnichsen, C.; Poschinger, H.; Plessen, G.; Klar, T. A.; Feldmann, J. Appl. Phys. Lett. 2002, 81, 171.

[9] Park, S. Y.; Stroud, D. Phys. Rev. Lett. 2005, 94, 217401.

[10] Jeng, S. C.; Hwang, S. J.; Yang, C. Y. Opt. Lett. 2009, 34, 455.

[11] Hao, Q.; Hegmann, T. J. Mater. Chem. 2008, 18, 3288.

[12] Hao, Q.; Kinkead, B.; Hegmann, T. Adv. Funct. Mater. 2008, 18, 212.

[13] Hao, Q.; Kinkead, B.; Marx, V. M.; Zhang, H. R.; Hegmann, T. C. ChemPhysChem 2009, 10, 1211.

[14] Hao, Q.; Kinkead, B.; Hegmann, T. Proc. SPIE 2008, 6911, 691106.

[15] Koenig, G. M.; Meli, M. V.; Park, J. S.; de Pablo, J. J.; Abbott, N. L. Chem. Mater. 2007, 19,1053.

[16] Lapanik, A.; Rudzki, A.; Kinkead, B.; Qi, H.; Hegmann, T.; Haase, W. Soft Matter 2012, 8, 8722.

[17] Prasad, S. K.; Sandhya, K. L.; Nair, G. G.; Hiremath, U. S.; Yelamaggad, C. V.; Sampath, S. Liq. Cryst. 2006, 33,1121.
[18] Prasad, S. K.; Sandhya, K. L.; Nair, G. G.; Rao, D. S. S. Curr. Sci. 2004, 86, 815.

[19] Nair, G. G.; Prasad, S. K.; Uma, H. S.; Yelamaggad, C. V. J. Appl. Phys. 2001, 90, 48.

[20] Prasad, S. K.; Rao, D. S. S.; Jeyagopal, P. Phys. Rev. E 2001, 64, 011706.

[21] Yuvaraj, A. R.; Kumar, S. Gen. Chem. 2018, 4, 1.

[22] Yuvaraj, A. R.; Rahman, M. L.; Yusoff, M. M.; Kumar, S. Micro Nano Lett. 2016, 12, 201.

[23] Biswas, T. K.; Yuvaraj, A. R.; Sarkar, S. M.; Malek, M. N. F. A.; Yusoff, M. M.; Arsad, S. E.; Rahman, M. L. Nanosci. Nanotechnol. Lett. 2017, 9, 100.

[24] Yuvaraj, A. R.; Yusoff, M. M.; Rahman, M. L. Mol. Cryst. Liq. Cryst. 2016, 631, 21.

[25] Yuvaraj, A. R.; Rahman, M. L.; Yusoff, M. M. Int. J. Spectrosc. 2016, 2016, 1.

[26] Rahman, M. L.; Hegde, G.; Kumar, S.; Tschierske, C.; Chigrinov. G. V. Opt. Mater. 2009, 32, 176.

[27] Ikeda, T. J. Mater. Chem. 2003, 13, 2037.

[28] Prasad, S. K.; Sandhya, K. L.; Rao, D. S. S.; Negi, Y. S. Phys. Rev. E 2003, 67, 051701/1.

[29] Rahman, M. L.; Biswas, T. K.; Sarkar, S. M.; Yusoff, M. M.; Yuvaraj, A. R.; Kumar, S. J. Colloid Interf. Sci. 2016, 478, 384.

[30] Rahman, M. L.; Hegde, G.; Yusoff, M. M.; Srinivasa, H. T.; Nurlin, S. A.; Fazli, M. A. M. N.; Kumar, S. New J. Chem. 2013, 37, 2460.

[31] Rahman, M. L.; Hegde, G.; Mahrokh, A.; Yusoff, M. M.; Kumar, S. J. Fluorine Chem. 2013, 156, 230.

[32] Rahman, M. L.; Jahimin, A.; Kumar, S.; Silong, S.; Rahman, M. Z. A. Phase Transit. 2009, 82, 228.

[33] Rahman, M. L.; Yusoff, M. M.; Kumar, S. RSC Adv. 2014, 4, 35089.

[34] Hao, Q.; Hegmann, T. J. Am. Chem. Soc. 2008, 130, 14201.

[35] Khatua, S.; Manna, P.; Chang, W. S.; Tcherniak, A.; Friedlander, E.; Zubarev, E. R.; Link, S. J. Phys. Chem. C 2010, 114, 7251.

[36] Brust, M.; Fink, J.; Bethell, D.; Schiffrin, D. J.; Kiely, C. Chem. Commun. 1995, 1655.

[37] Jacob, D. G.; Bishnu, P. K.; Eugene, R. Z. J. Am. Chem. Soc. 2007 129, 11653.

[38] Transfeld, R. V.; Collings, P. J. Phys. Rev. A 1982, 125, 2744.

Received March 30, 2018

Accepted April 27, 2018 